\title{
SOUTHERN THAILAND BRYOPHYTES II Epiphylls from the Phang-Nga area
}

\author{
T. Pócs ${ }^{1}$ and J. PodANI ${ }^{2}$ \\ ${ }^{1}$ Institute of Biology, Department of Botany, Eszterházy Károly College \\ H-3301 Eger, Pf. 43, Hungary; E-mail: colura@upcmail.hu \\ ${ }^{2}$ Department of Plant Systematics, Ecology and Theoretical Biology, Eötvös Loránd University \\ H-1117 Budapest, Pázmány Péter sétány 1/C, Hungary; E-mail: podani@ludens.elte.hu
}

(Received 29 September, 2014; Accepted 1 December, 2014)

The collection of epiphyllous bryophytes in the lowland rainforests of Phang-Nga province and in the neighbouring Phuket and Surat Thani provinces resulted in 54 liverwort and one moss species, of which 14 are new records for the bryoflora of Thailand. Epiphyllous bryophyte assemblages from nine localities are evaluated for species richness and beta diversity, as well as for their phytogeographical status.

Key words: Cololejeunea, Colura, diversity, Leptolejeunea, Marchantiophyta, Radula

\section{INTRODUCTION}

Sukkharak and Chantanaorrapint (2014) gave an account on the history of bryological research in Thailand, while an updated checklist of Thai liverworts was prepared by Lai et al. (2008). The first publication of this series (Chantanaorrapint and Pócs 2014) dealt with the bryophyte findings of the southernmost part of Thailand, mostly from Nakhon Si Thammarat province. The present paper deals with the epiphyllous collection carried out by Tamás Pócs and his wife, Sarolta Pócs, in Phang-Nga, Phuket and Surat Thani provinces of southern Thailand, in cooperation with the Chulalungkorn University in Bangkok (BCU) and Prince of Songkla University, Hat Yai, Songkhla (PSU). They visited 30 different localities during January 2007 in the three provinces, in a circle of $60 \mathrm{~km}$ radius around Phang-Nga town of which 9 were lowland rainforest habitats with epiphyllous vegetation (see the Enumeration below and Fig. 1). From these habitats, 54 epiphyllous species were identified of which 14 proved to be new for the flora of Thailand. The new records were 
compared in the present paper to the checklist of Thailand liverworts (Lai et al. 2008) and to the already mentioned first paper of this series. The next publication in this series, in co-authorship with Sahut Chantanaorrapint (Prince of Songkla University, PSU), will provide the results of our non-epiphyllous bryophyte collections from the same area. The records on the representatives of genus Lejeunea in Thailand have been published recently (Lee et al. 2014).

\section{MATERIALS AND METHODS}

\section{The localities of epiphyllous collections}

No. 07001: Phuket Prov., Thalang Distr., E side of Khao Phra Thaeo National Park, around Bangpae Waterfall, at 50-100 m alt., 08 02' 18.1" N, 99 23' 26.1" E. Seasonal lowland rainforest on granitic ground, with Streblus ilicifolia (Moraceae) dominant in the lower canopy and shrub layers. Date: 22 Jan. 2007.

No. 07002: Phuket Prov., Thalang Distr., beyond the western gate of Khao Phra Thaeo National Park, at 50-110 m alt., $08^{\circ} 01^{\prime} 39.5^{\prime \prime}$ N, 98 $21^{\circ} 46.9^{\prime \prime}$ E. Seasonal lowland rainforest with tall Dipterocarpaceae (Dipterocarpus, Shorea) in the high canopy, Arenga pinnata, Calamus sp. and the endemic Kerriodoxa elegans (Palmae) in the lower levels. Date: 22 Jan. 2007.

No. 07003: Phuket Prov., Kathu Distr., around Kathu Waterfalls 8 km SW of Phuket town, at $100-150 \mathrm{~m}$ alt., $07^{\circ} 55^{\prime} 57^{\prime \prime} \mathrm{N}, 98^{\circ} 19^{\prime} 22.6^{\prime \prime}$ E. Seasonal lowland rainforest on granitic ground. Date: 23 Jan. 2007.

No. 07007: Surat Thani Prov., Phanom Distr., at the S edge of Khao Sok National Park, at 98 $\mathrm{km}$ from Surat Thani town along the road half way between Phanom and Takuapa, at $80-120 \mathrm{~m}$ alt., $08^{\circ} 54^{\prime} 00.6^{\prime \prime} \mathrm{N}, 98^{\circ} 37^{\prime} 13.2^{\prime \prime}$ E. Karstic lowland rainforest at the $\mathrm{N}$ foot of a huge limestone cliff, S of Sok River. Date: 25 Jan. 2007.

No. 07012: Phang Nga Prov. and Distr., SE valley of Mt Khao Wang Ko, 3 km NW of Pak Ko village, around Klong Tam Waterfall, at 100-120 m alt., $08^{\circ} 30^{\prime} 25.15^{\prime \prime} \mathrm{N}, 98^{\circ} 27^{\prime} 00.40^{\prime \prime} \mathrm{E}$. Seasonal lowland rainforest on quartzite substrate. Date: 29 Jan. 2007.

No. 07014: Phang Nga Prov. and Distr., Nam Tok Raman Forest Park with waterfalls, 6 km W of Phang Nga town, at 20-50 m alt., $08^{\circ} 27^{\prime} 03.1^{\prime \prime}$ N, $98^{\circ} 26^{\prime} 55.3^{\prime \prime}$ E. Lowland rainforest with Dillenia indica in the high canopy in a rocky streamlet valley on quartzite. Many epiphylls. Date: 31 Jan. 2007.

No. 07015: Phang Nga Prov. and Distr., Sa Nang Manora Forest Park 6 km NNE of Phangna town, at $70-110 \mathrm{~m}$ alt., $08^{\circ} 30^{\prime} 44.7^{\prime \prime} \mathrm{N}, 98^{\circ} 32^{\prime} 18.9^{\prime \prime}$ E. Karstic primary rainforest with tall Kneme erratica (Myristicaceae), Sonneratia griffithii (Sonneratiaceae) and Terminalia bellerica (Combretaceae) trees along streamlet with cataracts on travertino deposits. Many epiphylls. Date: 31 Jan. 2007.

No. 07018: Phang Nga Prov., Thap Put Distr., $11 \mathrm{~km} \mathrm{~W}$ on road from Thap Put town, $6 \mathrm{~km}$ from Tham Thong Lang Dispensary, at 80-100 m alt., $08^{\circ} 32^{\prime} 18.5^{\prime \prime} \mathrm{N}, 98^{\circ} 34^{\prime} 00.0^{\prime \prime} \mathrm{E}$. Secondary rainforest along brook, on siliceous bedrock, with many epiphylls. Date: 1 Feb. 2007.

No. 07019: Phang Nga Prov., Thap Put Distr., Tao Tong Cataracts and Cave $3 \mathrm{~km} \mathrm{NW}$ of Ban Na village, $9 \mathrm{~km}$ SW from Thap Put town, at $66 \mathrm{~m}$ alt., $08^{\circ} 29^{\prime} 07.4^{\prime \prime} \mathrm{N}, 98^{\circ} 35^{\prime}$ 08.4" E. Karstic seasonal rainforest remnants with some epiphylls. Date: 1 Feb. 2007. 
All specimens were collected by S. and T. Pócs, and deposited in EGR and their duplicates in PSU. The material was identified by the senior author. The floristical analysis is concluded by evaluating the phytogeographical status of the epiphyllous bryophytes recorded.

\section{Sampling and data analysis}

From the shrub layer of each site, leaves covered by epiphylls were collected randomly. As their frequency differed greatly over habitats, the number of collected leaves was quite unequal. From a coenological point of view, each leaf was considered to be a different stand of the epiphyllous community (see Table 1). In this, the species new to the bryoflora of Thailand are emphasised in bold.

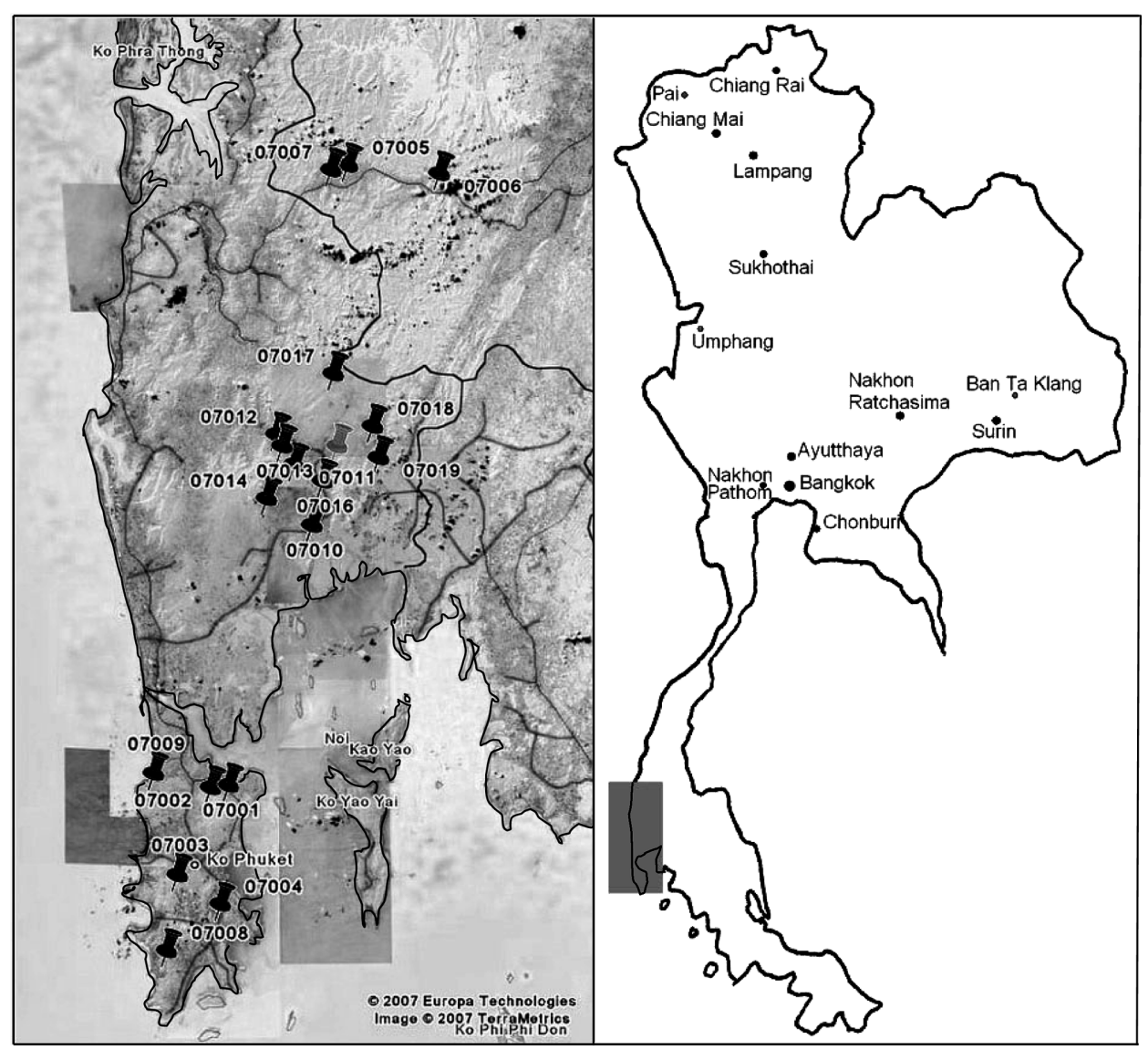

Fig. 1. The localities of the examined rainforest habitats 


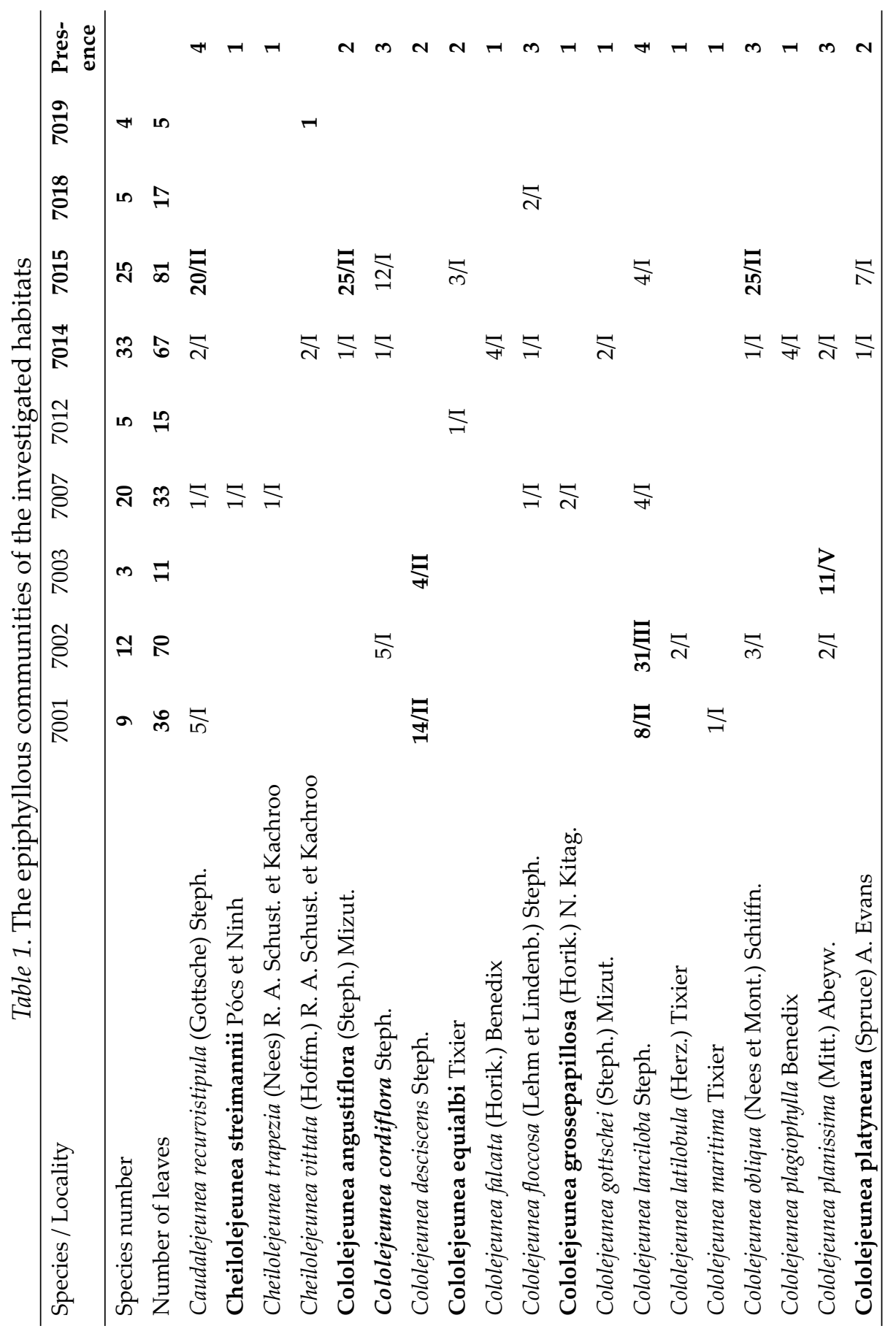




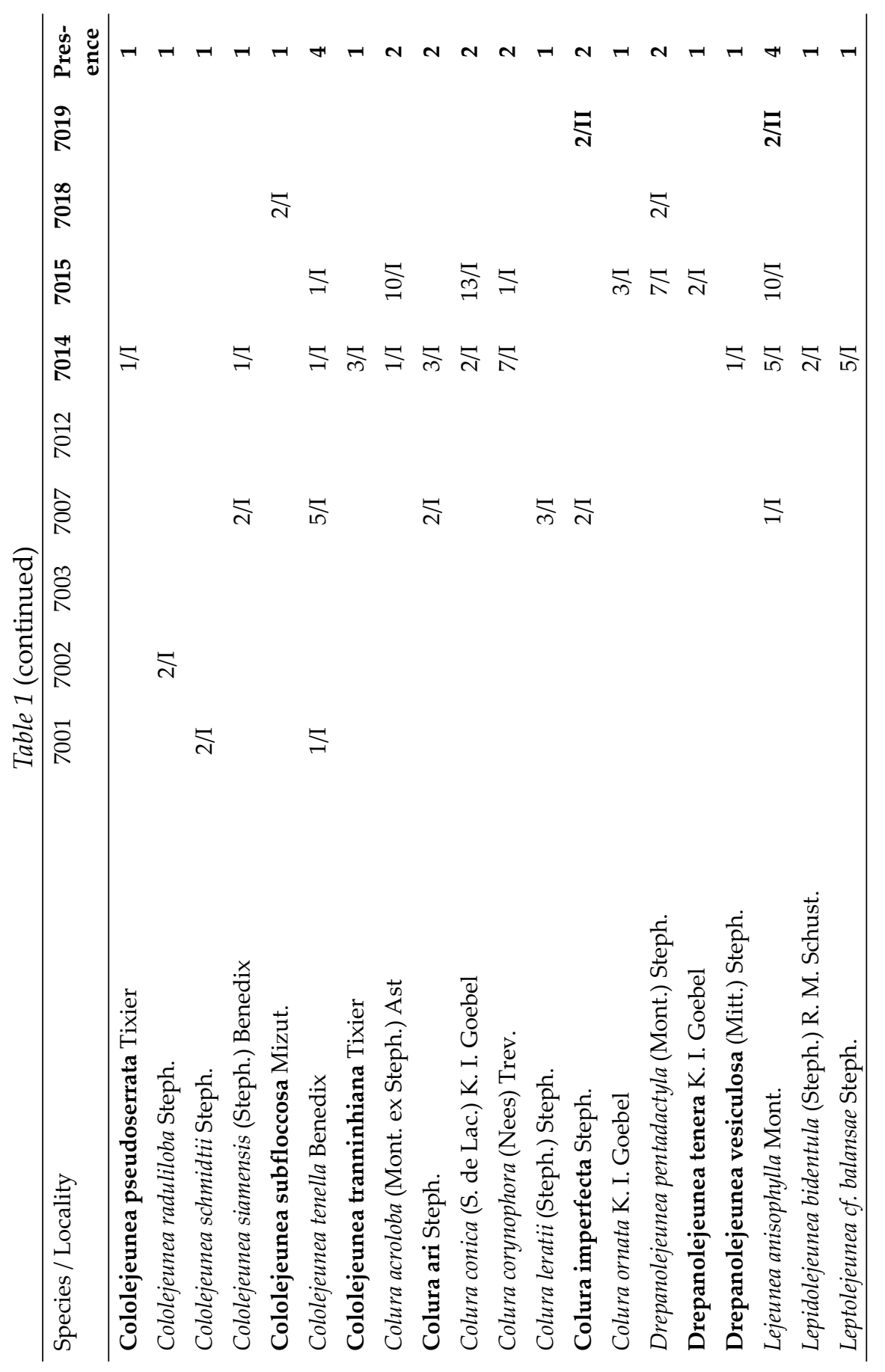




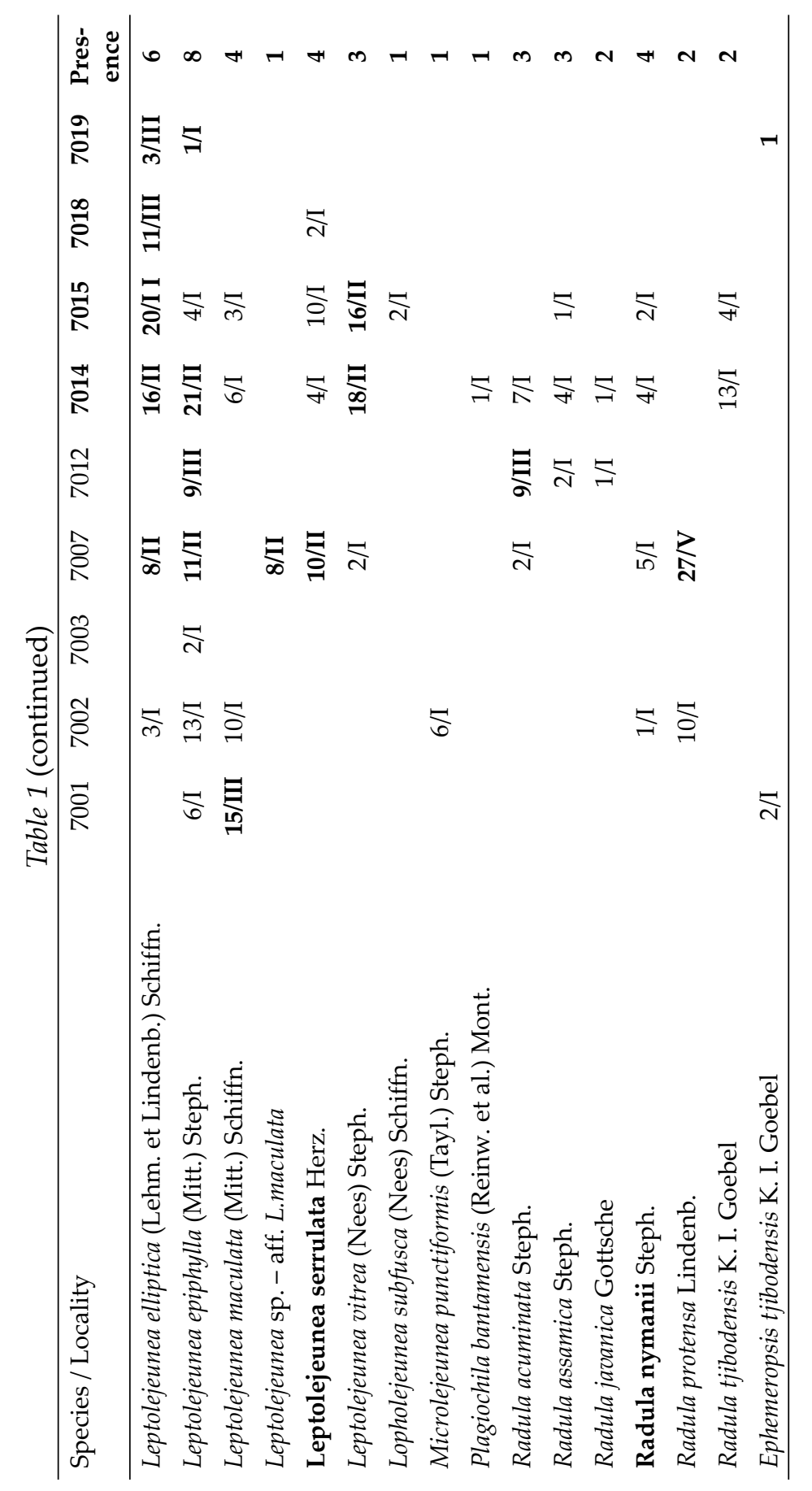


After identifying the species, we counted the number of leaves on which they appeared in each study site. Then, their abundance was estimated by calculating the percentage occupancy of the total number of leaves.

Based on the epiphyllous liverwort assemblage data, beta diversity and related structural phenomena were evaluated by the SDR simplex method developed by Podani and Schmera (2011) for presence-absence data, and Podani et al. (2013) for abundances. In the present case, to account for the differences in the number of leaves surveyed at the nine localities, we used the percentage relative frequency of each species as abundances, i.e., the number of leaves in which a given species was observed, divided by the total number of leaves sampled at the given site. For presence-absence data no such compensation was possible, so that results will be evaluated by considering the unbalanced sampling effort.

The essence of the method is that a pair of sites is compared by the Jaccard dissimilarity coefficient (p/a data) or its quantitative counterpart, the Ruzicka index (abundances). Dissimilarity is then partitioned into a fraction coming from richness (or abundance) differences between the two sites (D) and another fraction, which corresponds to species (or abundance) replacement (R). These two quantities - together with similarity (S), that is, the complement of dissimilarity - are used in ternary plots to specify the position of the given site pair. These three values always sum to 1 or $100 \%$. In the plot, the lower right corner corresponds to similarity, and lower left corner to richness (or abundance) difference, whereas the top corner is the replacement component. For example, if $S=R=D=0.33$, then the site pair will lie exactly in the centroid of the triangle. If the two sites are identical in species composition $(S=1, R=D=0)$, then the site pair will be positioned exactly on the bottom right corner. Calculated for all possible pairs of sites, the point cloud in the ternary diagram will inform us about the structure of community data. Beta diversity is understood as the sum of $D$ and $R$, whereas nestedness is calculated as the sum of $S$ and $D$, provided that $S>0$. In addition to graphical display, percentage contributions of the three components (S, D and R) to community structure may also be calculated.

\section{RESULTS}

Species new to the bryoflora of Thailand

Cheilolejeunea streimanii Pócs et Ninh, 2005, Acta Bot. Hung. 47: 162. Specimen collected: Surat Thani Prov., Phanom Distr., at the S edge of Khao Sok National Park, 07007/H (EGR). - An interesting species with caducous propagative shoots and narrow, often incurved leaf lobules. Hitherto known 
from a few localities, as the central part of Vietnam: Vu-Quang Nature Reserve, Australia: Queensland, Cape Tribulation and Sri Lanka, Southern Province, Hiniduma (Pócs and Ninh 2005). It was found always as epiphyllous. Probably more widespread in the Indomalesian Realm.

Cololejeunea angustiflora (Steph.) Mizut., 1965, J. Hattori Bot. Lab. 28: 113. (Fig. 2A) - Specimens collected: Phang Nga Prov. and Distr., Nam Tok Raman Forest Park, 07014/AV (EGR); Phang Nga Prov. and Distr., Sa Nang Manora Forest Park, 07015/P, R, S and U (EGR, PSU). - A variable species characterised by its yellowish (in herbarium, brownish), obovate to lanceolate leaves with crenulate margin and by its inflated lobule with an outstanding first tooth. It was described under different names (Leptocolea angustiflora Steph., Physocolea crenulata Herzog, Cololejeunea mackeeana Tixier, full synonymy in Zhu and So (2002). Widespread from Vietnam and Taiwan through Malaysia and Kalimantan to New Caledonia, Papua New Guinea and to the Fiji Islands (Grolle and Piippo 1984, Pócs 2012, Pócs and Piippo 2011).
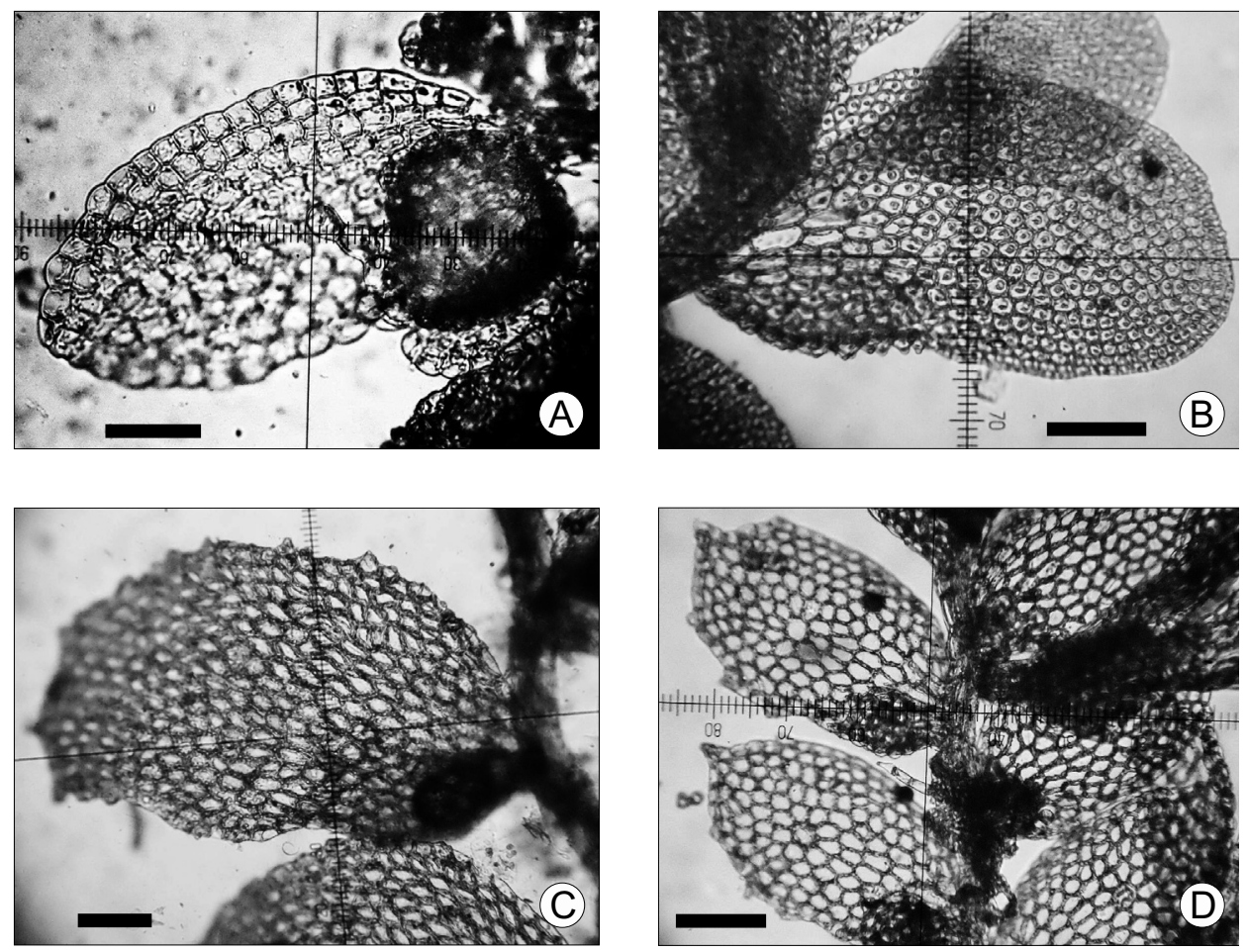

Fig. 2. Examples of species new to Thailand. $\mathrm{A}=$ Cololejeunea angustiflora (Steph.) Mizut.; $\mathrm{B}=$ C. platyneura (Spruce) A. Evans; $C=C$. pseudoserrata Tixier; D = Leptolejeunea serrulata Herz. (Scale bars represent $100 \mu \mathrm{m}$ ) 
Cololejeunea cordiflora Steph., 1895, Hedwigia 34: 246. - Phuket Prov., Thalang Distr., beyond the western gate of Khao Phra Thaeo National Park, 07002/G (EGR, PSU); Phang Nga Prov. and Distr., Nam Tok Raman Forest Park, 07014/BM (EGR); Sa Nang Manora Forest Park, 07015/AA (EGR, PSU). A widespread Indomalesian-Pacific species. Pócs and Piippo (2011) classified it as a subspecies of Cololejeunea trichomanis (Gottsche) Steph., but recent molecular investigations (Yu et al. 2013) seem to support its independent status.

Cololejeunea equialbi Tixier, 1970, Ann. Fac. Sci. Univ. Phnom Penh 3: 178. - Phang Nga Prov. and Distr., SE valley of Mt Khao Wang Ko, around Klong Tam Waterfall, 07012/F (EGR); Sa Nang Manora Forest Park, 07015/AZ (EGR, PSU). - A SE Asian-Pacific species known from S-China, Vietnam, Japan: Ryu-kyu, Philippines (Zhu and So 2001), Sulawesi (Eggers 2006), Seram (Mizutani 1986), Papua New Guinea (Pócs et al. 1994), Fiji Islands (Pócs et al. 2011).

Cololejeunea grossepapillosa (Horik.) N. Kitag., 1981, Hikobia suppl. 1: 68. - Phang Nga Prov. and Distr., Sa Nang Manora Forest Park, 07015/AN (EGR). - A Palaeotropical species, widespread in sub-Saharan Africa (Wigginton 2009, sub Aphanolejeunea capensis S. Arnell) and in SE Asia (Zhu and So 2001, sub Aphanolejeunea grossepapillosa Horik.).

Cololejeunea platyneura (Spruce) A. Evans, 1902, Mem. Torrey Bot. Club 8: 172. (Fig. 2B) - Phang Nga Prov. and Distr., Nam Tok Raman Forest Park, 07014/BC (EGR); Sa Nang Manora Forest Park 07015/AB (EGR, PSU). - A widespread Pantropical species (Tixier 1991), known under many synonyms (Zhu and So 1998).

Cololejeunea pseudoserrata Tixier, 1979, Nova Hedwigia 31: 770. (Fig. 2C) - Phang Nga Prov. and Distr., Nam Tok Raman Forest Park, 07014/AY (EGR). - A Melanesian species known from New Caledonia, Irian Jaya, Papua New Guinea, Solomon Islands (Pócs and Piippo 2011), Fiji Islands (Pócs et al. 2011).

Cololejeunea subfloccosa Mizut., 1984, J. Hattori Bot. Lab. 57: 168. Phang Nga Prov., Thap Put Distr., $11 \mathrm{~km} \mathrm{~W}$ on road from Thap Put, 07018/B (EGR, PSU). - SE Asian species hitherto known only from S-China and Japan (Zhu and So 2001). As it is easily confused from the widespread C. floccosa, maybe the species is more widespread than thought.

Cololejeunea tranninhiana Tixier, 1974, Ann. Hist.-Nat. Mus. Nat. Hung. 66: 97. - Phang Nga Prov. and Distr., Nam Tok Raman Forest Park, 07014/AK and $A L$ (EGR, PSU). - Previously known only from the northern part of Vietnam, although Cololejeunea pseudoplagiophylla P. C. Wu et P. J. Lin (Wu and Lin 1978), distributed in India, South China and Vietnam (Zhu and So 1999, 2001) might be its later synonym.

Colura ari (Steph.) Steph., 1916, Sp. Hepat. 5: 936. - Surat Thani Prov., Phanom Distr., at the S edge of Khao Sok National Park, 07007/G (EGR, PSU); 
Phang Nga Prov. and Distr., Nam Tok Raman Forest Park, 07014/AG (EGR ). A widespread Indomalesian-Pacific species known from India and Sri Lanka to Australia, Philippines, New Caledonia, New Guinea, and Samoa (Zhu and So 2001) and to the Fiji Islands (Campbell 1971).

Colura imperfecta Steph., 1916, Sp. Hepat. 5: 938. - Phang Nga Prov.: Thap Put Distr., Tao Tong Cataracts and Cave $3 \mathrm{~km}$ NW of Ban Na village, 07019/A (EGR, PSU). - Malesian-Pacific species distributed from Java to New Guinea, the Solomon and Fiji Islands (Pócs in Gradstein et al. 2006, Jovet-Ast 1954, Pócs 2013).

Drepanolejeunea tenera K. I. Goebel, 1928, Ann. Jard. Bot. Buitenzorg 39: 20. - Phang Nga Prov. and Distr., Sa Nang Manora Forest Park, 07015/Q (EGR). - Malesian-Pacific species widespread from Java to Fiji Islands (Miller et al. 1983).

Drepanolejeunea vesiculosa (Mitt.) Steph., 1913, Sp. Hepat. 5: 356. Phang Nga Prov. and Distr., Nam Tok Raman Forest Park, 07014/BO (EGR). - Widespread Palaeotropical species known from Africa throughout tropical Asia and Australia to the Pacific (Zhu and So 2001).

Leptolejeunea serrulata Herz., 1942, Flora 135: 126. (Fig. 2D) - Surat Thani Prov., Phanom Distr., at the S edge of Khao Sok National Park, 07007/J (EGR, PSU); Phang Nga Prov. and Distr., Nam Tok Raman Forest Park, 07014/ $B O$ (EGR, PSU); Sa Nang Manora Forest Park, 07015/AF (EGR, PSU); Thap Put Distr., $11 \mathrm{~km} \mathrm{~W}$ on the road from Thap Put town, 07018/D (EGR, PSU). Previously known only from Vietnam, Peninsular Malaysia, Irian Jaya, Papua New Guinea and Australia (Chuah-Petiot 2011, Grolle and Piippo 1984, Herzog 1942, Lee et al. 2014, Pócs 1965, Pócs and Streimann 1999).

Radula nymanii Steph., 1910, Sp. Hepat. 4: 229. - Phuket Prov., Thalang Distr., Beyond the western gate of Khao Phra Thaeo National Park, 07002/J (EGR); Surat Thani Prov., Phanom Distr., at the $S$ edge of Khao Sok National Park, 07007/Z (EGR, PSU); Phang Nga Prov. and Distr., Nam Tok Raman Forest Park, 07014/BR (EGR, PSU); Sa Nang Manora Forest Park, 07015/AO (EGR). - Widespread in the whole Indomalesian and Pacific Region, from Sri Lanka to the Society Islands (Miller et al. 1983).

\section{Phytogeographical analysis}

As the species list given above demonstrates, a number of quite widespread Indomalesian, Palaeotropical species are newly recorded for the study area. This suggests that the bryoflora of the southern part of Thailand is still quite unexplored. From the history of the bryological research of the country (Sukkharak and Chantanaorrapint 2014) it is obvious that previous research concentrated on the northern and central Thailand. The same is also apparent 
from recent revisions (e.g. Lee et al. 2014), as most of the new records originate from southern Thailand, which is climatically and floristically quite different from the central and northern parts. Van Welzen et al. (2011) proposed four main phytogeographical regions, Northern, Eastern, Central and Southern Thailand, and our study area belongs to the last one. The previously and recently described endemic species originate mostly from the mountainous areas (e.g. Drepanolejeunea laciniata - He et al. 2012, Cololejeunea ramromensis - Chantanaorrapint and Pócs 2014 or Drepanolejeunea actinogyna - Inuthai et al. 2014). The lowland rainforests of southern Thailand are dominated by the more widespread Indomalesian, Palaeotropical or Pantropical species. This phenomenon is even more expressed if we take into account species abundances. An analysis on the geographical distribution of epiphyllous species provides the following results (see also Figs 3-4).

Indochinese subendemics: 4 species. As mentioned above, strict endemics do not occur among the lowland epiphylls of this area. Indochinese subendemics are distributed from Khasia and Burma to Vietnam and to Peninsular Malaysia: Cololejeunea maritima, Cololejeunea siamensis, Cololejeunea tranninhiana, Radula assamica.

Southeast Asian elements: 4 species. Distributed in Indochina, South China and Japan (some of them reaching Australia or the Pacific Islands, marked by ${ }^{*}$ ): ${ }^{*}$ Cololejeunea equialbi, Cololejeunea schmidtii, Cololejeunea subfloccosa, ${ }^{*}$ Leptolejeunea serrulata.

Melanesian element: 1 species. Hitherto known from New Caledonia to the Fiji Islands: Cololejeunea pseudoserrata.

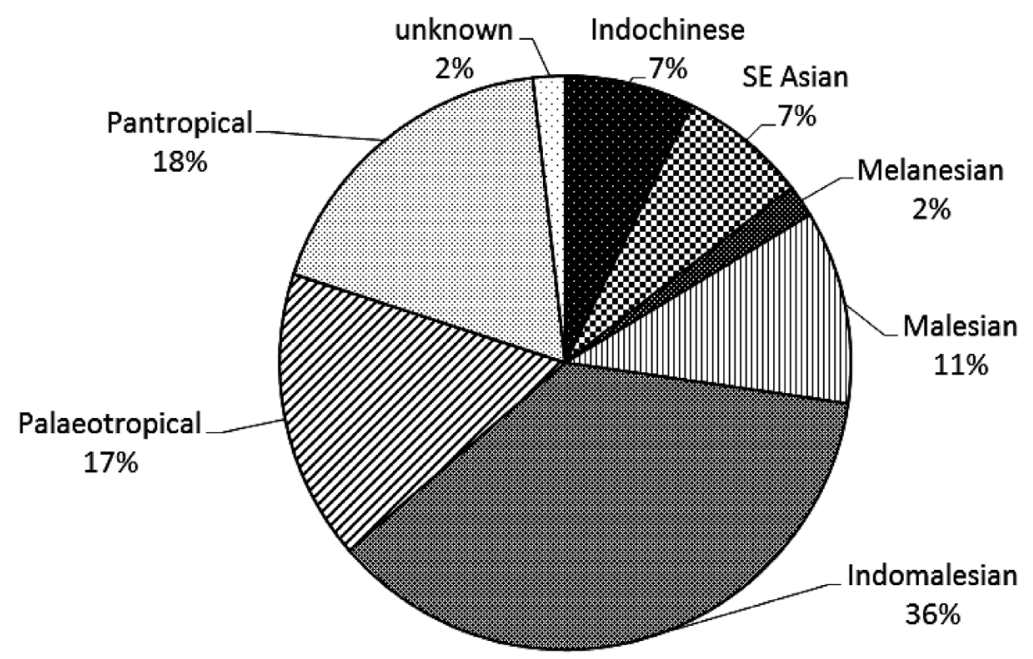

Fig. 3. Proportion of area types based on the number of species 
Malesian elements: 6 species. Distributed from Java throughout tropical Asia to New Guinea (or to the Pacific, marked by ${ }^{*}$ ): Cheilolejeunea vittata, ${ }^{*} \mathrm{Co}-$ lolejeunea angustiflora, Cololejeunea plagiophylla, Colura ornata, ${ }^{*}$ Drepanolejeunea tenera, *Plagiochila bantamensis.

Indomalesian elements: 19 species. Distributed from India or Sri Lanka to New Guinea (or also in the Pacific Islands, marked by ${ }^{*}$ ): ${ }^{*}$ Caudalejeunea recurvistipula, Cheilolejeunea streimannii, * Cololejeunea cordiflora, Cololejeunea desciscens, Cololejeunea tenella, ${ }^{*}$ Colura acroloba, ${ }^{*}$ Colura ari, ${ }^{*}$ Colura conica, ${ }^{*}$ Colura corynophora, *Colura imperfecta, *Colura leratii, Leptolejeunea balansae, Microlejeunea punctiformis, Radula acuminata, ${ }^{*}$ Radula javanica, ${ }^{*}$ Radula nymanii, Radula protensa, *Radula tjibodensis, ${ }^{*}$ Ephemeropsis tjibodensis.

Palaeotropical elements: 9 species. Distributed from tropical Africa (or only from its islands in the Indian Ocean, marked by*) to tropical Asia, and partly to Australasia or to the Pacific Islands: Cheilolejeunea trapezia, Cololejeunea grossidens, Cololejeunea raduliloba, Drepanolejeunea pentadactyla, Drepanolejeunea vesiculosa, Lejeunea anisophylla, ${ }^{*}$ Lepidolejeunea bidentula, Leptolejeunea epiphylla, ${ }^{*}$ Leptolejeunea vitrea.

Pantropical elements: 10 species. Distributed in tropical Africa, America, Asia and part of them also in Australasia and in the Pacific Islands: Cololejeunea falcata, Cololejeunea floccosa, Cololejeunea lanciloba, Cololejeunea latilobula, Cololejeunea obliqua, Cololejeunea planissima, Cololejeunea platyneura, Leptolejeunea elliptica, Leptolejeunea maculata, Lopholejeunea subfusca.

Unknown distribution: 1 species. Leptolejeunea aff. maculata is perhaps a new species.

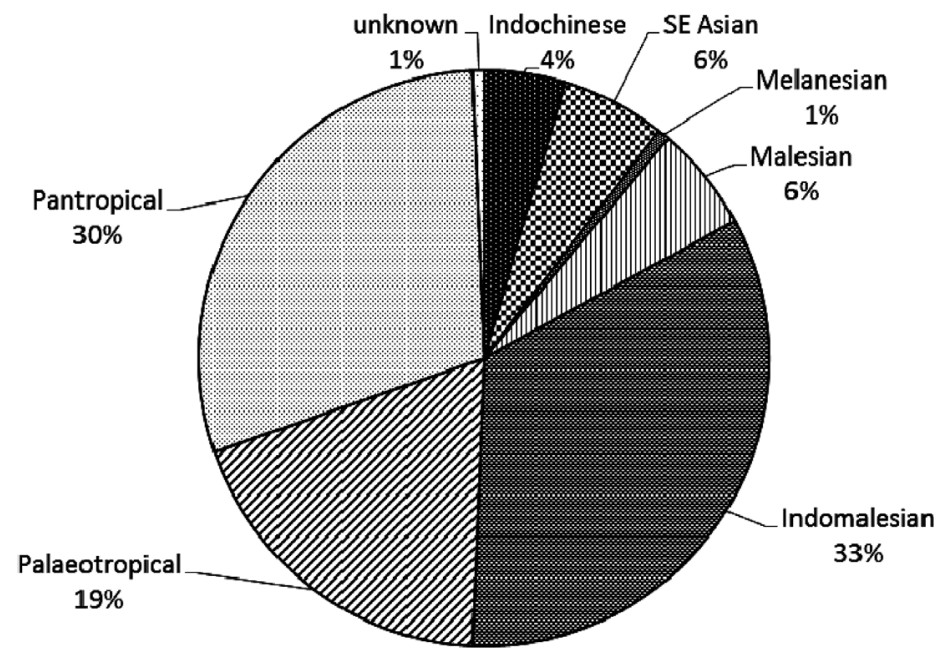

Fig. 4. Proportion of area types, when abundance of species is considered 
Beta diversity in the 9 localities

Figure $5 a$ shows the ternary plot for the presence-absence data. The point cloud lies along the beta diversity $(D+R)$ side of the triangle, such that richness difference $(\mathrm{D})$ is the highest contributor $(50 \%)$, while species replacement is lower $(37 \%)$. These shares may be a result of different sampling effort in the different sites, because fewer leaves are expected to contain fewer species. The points are far from the $\mathrm{S}$ corner, indicating that the sites have very low similarity based on the presence of epiphyllous liverworts. Similarity amounts only to $13 \%$, and this is not influenced by sampling because all pairs of sites are far from the $S$ corner irrespective of the number of leaves examined. The data are considerably nested (61\%), but this nestedness comes in most part from the richness difference component.

Figure $5 b$ illustrates diversity relationships for the relative frequency (abundance) data. Beta diversity is only a little higher than for the presenceabsence case $(90 \%)$, but it is mostly explained by abundance replacement ( $R$ $=69 \%$ ) and much less by abundance differences (21\%). Similarity remains as low as for the presence-absence data $(\mathrm{S}=10 \%)$. Consequently, nestedness is fairly low $(29 \%)$ in the abundance case: sites containing species with large abundances do not include the liverworts of poorer sites.

\section{DISCUSSION}

The identification of the epiphyllous material resulted in the records of 14 species new to the bryoflora of Thailand. Their phytogeographical analysis revealed the dominance of widely distributed Indomalesian and Pantropical

a

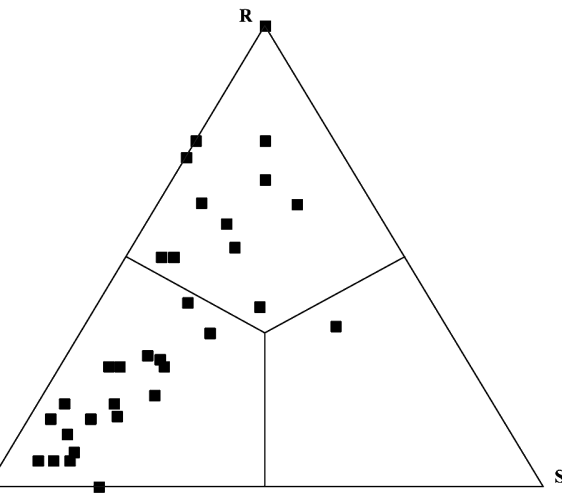

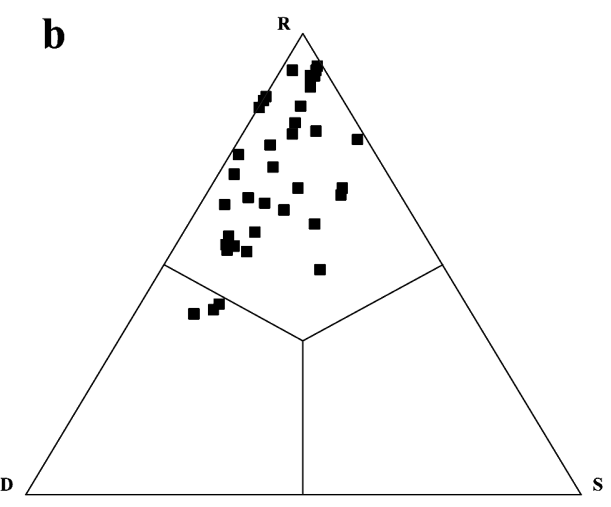

Fig. 5. Ternary (or simplex) plots for the epiphyllous liverwort assemblages based on presence-absence (a) and abundances (b). Closeness of the point cloud to the beta diversity side $(\mathrm{D}+\mathrm{R})$ is indicative of high overall beta diversity in the study area 
species in the lowland rainforests, while the proportion of near endemic Indochinese species is relatively low.

Beta diversity of bryophytes and other cryptogamic groups has been investigated fairly commonly, using the classical additive or multiplicative models for alpha, beta and gamma diversity. Studies rarely focus exclusively on epiphyllous assemblages, however. A noted example is Kraichak (2013), who evaluated the relationship between beta diversity of epiphyllous communities and microclimate in French Polynesia, using a distance-based approach. This paper presents the first application of a novel method for analysing beta diversity and related phenomena to epiphyllous bryophytes. The SDR simplex analysis revealed extremely high beta diversity - and low overall similarity - for the study sites, irrespective of the data type used. In the presence-absence case the high diversity values are mostly explained by different sampling effort, i.e. by the fact that the number of leaves examined in the sites was unequal (ranging from 5 to 81). For abundances, the picture is different: although total beta diversity is almost the same, the replacement component dominates, meaning that in the epiphyllous assemblages there is a very high turnover of abundant species. This is obvious from the data, despite the unequal sample sizes.

Nestedness is fairly high for presence-absences, which may have to do with unequal sample sizes and that there are at least 1-2 species shared by most localities. Leptolejeunea epiphylla appears in all but one site, so that this single species is responsible by itself for the nested structure. For abundances, this is no longer the case: high abundances are rarely shared by the sites leading to low overall nestedness.

Acknowledgements - The senior author is indebted to Prof. Obchant Thaitong (BCU) and to Dr Sahut Chantanaorrapint (PSU) for their multifold support to write this paper.

\section{REFERENCES}

Campbell, E. O. (1971): Liverworts collected in Fiji by A. C. Smith and W. Greenwood. - J. Roy. Soc. New Zealand 1: 7-30. doi: 10.1080/03036758.1971.10419353

Chantanaorrapint, S. and Pócs, T. (2014): Southern Thailand bryophytes I, with description of Cololejeunea ramronensis. - In: Telnov, D. (ed.): Biodiversity, biogeography and nature conservation in Wallacea and New Guinea. The Entomological Society of Latvia, Riga, Vol. 2, pp. 113-122.

Chuah-Petiot, M. S. (2011): A checklist of Hepaticae and Anthocerotae of Malaysia. - Polish Bot. J. 56(1): 1-44.

Eggers, J. (2006): New bryophyte taxon records for tropical countries 6. - Tropical Bryol. 27: $107-111$. 
Gradstein, S. R., Wilson, R., Ilkiu-Borges, A. L. and Heinrichs, J. (2006): Phylogenetic relationships and neotenic evolution of Metzgeriopsis (Lejeuneaceae) based on chloroplast DNA sequences and morphology. - Bot. J. Linn. Soc. 151: 293-308. doi: 10.1111/j.1095-8339.2006.00531.x

Grolle, R. and Piippo, S. (1984): Annotated catalogue of Western Melanesian bryophytes. I. Hepaticae and Anthocerotae. - Acta Bot. Fenn. 125: 1-86.

He, Q., Zhu, R-L., Chantanaorrapint, S., Kornochalert, S. and Printarakul, N. (2012): Drepanolejeunea laciniata (Lejeuneaceae), a new species from northern Thailand. Cryptogamie, Bryol. 33: 291-298. doi: 10.7872/cryb.v33.iss3.2012.291

Herzog, Th. (1942): Revision der Lebermoosgattung Leptolejeunea Spr. in der Indomalaya. - Flora 135: 377-434.

Inuthai, J., Zhu, R.-L. and Chantanaorrapint, S. (2014): Drepanolejeunea actinogyna (Lejeuneaceae), a new species from southern Thailand. - The Bryologist 117: 165-169. doi: 10.1639/0007-2745-117.2.165

Jovet-Ast, S. (1954, “1953”): Le genre Colura Hépatiques, Lejeuneacées, Diplasiae. - Rev. Bryol. Lichénol. 22: 206-312.

Kraichak, E. (2013): Adaptive traits and community assembly of epiphyllous bryophytes. - Thesis, University of California, Berkeley.

Lai, M.-J., Zhu, R.-L. and Chantanaorrapint, S. (2008): Liverworts and hornworts of Thailand: an updated checklist and bryofloristic accounts. - Ann. Bot. Fenn. 45: 321-341. doi: $10.5735 / 085.045 .0501$

Lee, G. E., Pócs, T., Chantanaorrapint, S., Damanhuri, A. and Latiff, A. (2014): An account of the genus Lejeunea (Marchantiophyta: Lejeuneaceae) in Thailand, including seven newly recorded species. - Cryptogamie, Bryol. 35(3): 247-259. doi: 10.7872/cryb.v35. iss3.2014.247

Miller, H. A., Whittier, H. O. and Whittier, B. A. (1983): Prodromus Florae Hepaticarum Polynesiae. - J. Cramer, Vaduz, 423 pp.

Mizutani, M. (1986): Lejeuneaceae from Seram Island, Indonesia. - J. Hattori Bot. Lab. 61: 299-308.

Pócs, T. (1965): Prodrome de la bryoflore du Vietnam. - Acta Acad. Paed. Agriensis, n. ser. 3: 453-495.

Pócs, T. (2012): Bryophytes from Fiji Islands, VI. The genus Cololejeunea Raddi (Jungermanniopsida), with the description of seven new species. - Acta Bot. Hung. 54: 145-188. doi: 10.1556/ABot.54.2012.1-2.16

Pócs, T. (2013): The genus Colura (Lejeuneaceae) in New Guinea and in the neighboring areas. - Chenia 11: 12-38.

Pócs, T. and Ninh, T. (2005): Contribution to the bryoflora of Vietnam, VI. On the liverwort flora of Vu Quang Nature Reserve. - Acta Bot. Hung. 47(1-2): 151-171. doi: 10.1556/ ABot.47.2005.1-2.14

Pócs, T. and Piippo, S. (2011): Bryophyte flora of the Huon Peninsula, Papua New Guinea. LXXIV. Cololejeunea (Lejeuneaceae, Hepaticae). - Acta Bryolichenol. Asiatica 4: 59-137.

Pócs, T. and Streimann, H. (1999): Epiphyllous liverworts from Queensland, Australia. Bryobrothera 5: 165-172.

Pócs, T., Mizutani, M. and Piippo, S. (1994): Bryophyte flora of Huon Peninsula, Papua New Guinea. LXV. Preliminary contributions on Lejeuneaceae (Hepaticae) 1. - Ann. Bot. Fennici 31: 179-190.

Pócs, T., Sass-Gyarmati, A., Naikatini, A., Tuiwawa, M., Braggins, J., Pócs, S. and von Konrat, M. (2011): New liverwort (Marchantiophyta) records for the Fiji Islands. - Telopea 13: 455-494. 
Podani, J. and Schmera, D. (2011): A new conceptual and methodological framework for exploring and explaining pattern in presence-absence data. - Oikos 120: 1625-1638. doi: 10.1111/j.1600-0706.2011.19451.x

Podani, J., Ricotta, C. and Schmera, D. (2013): A general framework for analyzing beta diversity, nestedness and related community-level phenomena based on abundance data. - Ecol. Complexity 15: 52-61. doi: 10.1016/j.ecocom.2013.03.002

Sukkharak, P. and Chantanaorrapint, S. (2014): Bryophyte studies in Thailand: past, present and future. - Cryptogamie, Bryol. 35: 5-17. doi: 10.7872/cryb.v35.iss1.2014.5

Tixier, P. (1991): Bryophyta exotica 9. Quelques Lejeuneaceae (Hépatiques) nouvelles pour l'Amérique de Sud. - Candollea 46: 267-302.

Van Welzen, P. C., Madern, A., Raes, N., Parnell, J. A. N., Byrne, C., Curtis, T., Macklin, J., Trias-Blasi, A., Prajaksood, A., Simpson, D. A., Bygrave, P., Dransfield, S., Kirkup, D. W., Moat, J., Wilkin, P., Couch, C., Boyce, P. C., Chayamarit, K., Chantaranothai, P., Esser, H.-J., Jebb, M. H. P., Larsen, K., Larsen, S. S., Nielsen, I., Meade, C., Middleton, D. J., Pendry, C. A., Muasya, A. M., Pattharahirantricin, N., Pooma, R., Suddee, S., Staples, G. W., Sungkaew, S. and Teerawatananon, A. (2011): Chapter 11. The current and future status of floristic provinces in Thailand. - In: Trisurat, Y., Shrestha, R. P. and Alkemade, R. (eds): Land use, climate change and biodiversity modeling: Perspectives and applications. IGI Global, Hershey, USA, pp. 219-247. doi: 10.4018/978-160960-619-0.ch011

Wigginton, M. J. (2009): Checklist and distribution of the liverworts and hornworts of subSaharan Africa, including the East African Islands (edition 3, 24 January 2009). - Tropical Bryol. Res. Reports 8: 1-116.

Wu, P.-C. and Lin, P.-J. (1978): A preliminary observation on the Hepaticae of the island Hainan, China, and their phytogeographical relationships. - Acta Phytotax. Sin. 16: $56-71$.

Yu, Y., Pócs, T., Schäfer-Verwimp, A., Heinrichs, J., Zhu, R.-L. and Schneider, H. (2013): Evidence for rampant homoplasy in the phylogeny of the epiphyllous liverwort genus Cololejeunea (Lejeuneaceae). - Syst. Bot. 38(3): 553-563. doi: 10.1600/036364413X670304

Zhu, R.-L. and So, M. L. (1998): Notes on the taxonomy of Cololejeunea platyneura (Hepaticae, Lejeuneaceae). - Ann. Bot. Fenn. 35: 229-232.

Zhu, R.-L. and So, M. L. (1999): New records of Cololejeunea (Lejeuneaceae, Hepaticae) for China and Vietnam. - Bot. Bull. Acad. Sin. 40: 165-171.

Zhu, R.-L. and So, M. L. (2001): Epiphyllous liverworts of China. - Nova Hedwigia, Beih. 121: $1-418$.

Zhu, R.-L. and So, M. L. (2002): Reappraisal of Cololejeunea angustiflora, C. ciliata, C. flavicans, C. javanica, and C. mackeeana (Hepaticae, Lejeuneaceae). - Bryologist 105: 431-438. doi: 10.1639/0007-2745(2002)105[0431:ROCACC]2.0.CO;2 